\title{
Spatiotemporal Variations of Bioaerosols in the Vicinity of an Animal Feeding Operation Facility in the US
}

\author{
Di Hu${ }^{1}$, Lingjuan Wang-Li ${ }^{*}$, Otto D. Simmons III' ${ }^{1}$, John J. Classen ${ }^{1}$, Jason A. Osborne ${ }^{2}$ \\ ${ }^{1}$ Department of Biological and Agricultural Engineering, North Carolina State University, Raleigh, NC, USA \\ ${ }^{2}$ Department of Statistics, North Carolina State University, Raleigh, NC, USA \\ Email: ${ }^{\text {Iwang5@ncsu.edu }}$
}

Received 25 May 2015; accepted 27 June 2015; published 30 June 2015

Copyright (C) 2015 by authors and Scientific Research Publishing Inc.

This work is licensed under the Creative Commons Attribution International License (CC BY). http://creativecommons.org/licenses/by/4.0/

(c) (i) Open Access

\begin{abstract}
Bioaerosol emissions from animal feeding operation (AFO) facilities are of increasing interest due to the magnitude of the emissions and their potential health effect on local communities. There is limited information about fate and transport of AFO bioaerosol emissions. In this study, concentrations of airborne bacteria and fungi were measured at four ambient stations in four wind directions surrounding an egg production farm through winter, spring and summer using Andersen six-stage samplers. Mean concentrations of ambient bacteria and fungi ranged from $8.7 \times 10^{2} \mathrm{CFU}$ $\mathrm{m}^{-3}$ to $1.3 \times 10^{3} \mathrm{CFU} \mathrm{m} \mathrm{m}^{-3}$ and from $2.8 \times 10^{2} \mathrm{CFU} \mathrm{m} \mathrm{m}^{-3}$ to $1.4 \times 10^{3} \mathrm{CFU} \mathrm{m}^{-3}$, respectively. Ambient bacterial concentrations were not significantly different over the seasons, while ambient fungal concentrations were the highest in summer and the lowest in winter. There were significant differences between downwind and upwind bacterial concentrations $(p<0.0001)$. Downwind bacterial and fungal concentrations responded differently to the influencing factors. Bacterial concentrations were quadratically correlated with wind vector (combined effects of wind speed and direction) and emission rate, were positively correlated with temperature, and were negatively correlated with solar radiation. Fungal concentrations were positively correlated with temperature, $\mathrm{RH}$, and emission rate, and were negatively correlated with wind vector.
\end{abstract}

\section{Keywords}

Animal Feeding Operation, Bioaerosol, Bacteria, Fungi, Temproal Variation, Spatial Variation

\section{Introduction}

While providing food for human-beings, animal feeding operations (AFOs) also emit significant amounts of ${ }^{*}$ Corresponding author.

How to cite this paper: Hu, D., Wang-Li, L., Simmons III, O.D., Classen, J.J. and Osborne, J.A. (2015) Spatiotemporal Variations of Bioaerosols in the Vicinity of an Animal Feeding Operation Facility in the US. Journal of Environmental Protection, 6, 614-627. http://dx.doi.org/10.4236/jep.2015.66056 
bioaerosols. By definition, bioaerosols are airborne biological particles that may consist of bacteria, fungi, and other microorganisms. Once emitted, bioaerosols can travel short and long distances in the air [1]-[4]. Concentrations of bioaerosols are usually higher than background levels in the surrounding areas of AFO facilities that may lead to higher exposure levels to people living nearby.

Like other aerosols, the concentrations of bioaerosol in the ambient air vary due to the spatial and temporal effects [5]. Normally bioaerosol concentration decreases with increasing distance from the emission source [2], [6]. Another factor that affects bioaerosol concentrations is inactivation [5]. Bioaerosols lose their viability over time due to the conditions to which they are exposed [7]-[9]. Meteorological factors (i.e., temperature, relative humidity, and solar radiation) affect the fate and transport of bioaerosols in ambient air. Bioaerosols tend to lose their original particle size and shape, and even lose their viability in low RH due to dehydration. Some gramnegative bacteria are most stable at an intermediate $\mathrm{RH}$ of $60 \%$, and some species show a greater survival at high RH levels [10] [11]. On the other hand, several studies reported increased death rates for some species of gram-negative bacteria at RH levels above 50\% (50\% - 90\%) [12] [13]. The viability of airborne microorganisms will also depend on the range of temperature. Microbes will decrease their viability as temperature increases; they may also lose viability under extremely low temperatures [7]. Generally, bacteria survival rate decreased at temperatures above $24^{\circ} \mathrm{C}$ [10]. In contrast, airborne fungi seem to prefer higher temperatures. Sabariego et al. [14] has reported optimum temperature for several fungal species to range from $13^{\circ} \mathrm{C}$ to $29^{\circ} \mathrm{C}$. Studies confirmed that fungi concentrations were positively correlated with higher RHs and temperatures [13]. Solar radiation is another important factor for the outdoor airborne microorganisms. Ulevičius et al.'s [15] study showed a lethal effect of solar radiation on airborne fungi in ambient air.

Although characterizing bioaerosols in animal production environments has been a topic for numerous studies [2]-[4] [16]-[23], knowledge gaps exist in how the ambient concentrations of bioaerosols are affected by emission rate, meteorological conditions, and other influencing factors. The objectives of this research were to quantify bacterial and fungal concentrations in the vicinity of the sources and to identify the relationships between ambient bacterial and fungal concentrations and possible influencing factors. The newly gained knowledge will provide fundamental information for studies on fate and transport of bioaerosols emitted from AFOs as well as for assessment of potential health effect of AFO bioaerosol emissions to the people living nearby the AFO facilities.

\section{Materials and Methods}

Airborne bacteria and fungi samples were collected at five locationson a commercial egg production farm (also known as the layer farm) in North Carolina. As illustrated in Figure 1, this layer farm consisted of fourtunnel ventilated high-rise houses (houses 1 - 4); two cross ventilated high-rise houses (houses 5 - 6) and two naturally ventilated shallow-pit houses (houses 93 and 103). Sampling station 1 (ST1) was located immediately upstream of the primary representative exhaust fan inside house 4, a tunnel-ventilated high-rise barn holding approximately 95,000 hens on the upper floor of the house. Manure fell down into the first floor and was stored there for up to one year [24]. The other four sampling stations (ST2-ST5) were in the ambient locations surrounding the farm in four different directions. A $10 \mathrm{~m}$ weather tower was located between house 2 and house 3 at the east end. Solar radiation (Model LI-200SL, LiCOR, Lincoln, NE), wind speed and direction (Model 05103L, R.M. Young Company, Michigan), ambient temperature and relative humidity (Vaisala HMT100, Vaisala Inc., Woburn, MA) sensors were mounted on the top of the tower to take continuous measurements at one-minute interval. All the sensors were approximately $1.5 \mathrm{~m}$ higher than the building ridgelines.

To investigate temporal and spatial variations on ambient bioaerosol concentrations, a total of 14 sampling events (days) were conducted in winter (December 2010-January 2011), spring (March-May 2011), and summer (June-July 2011). During each sampling event, 12 sampling tests with 6 tests for bacteria and 6 tests for fungi were conducted from 10:00 a.m. to 2:25 p.m. The sample sizes are listed in Table 1. More information about the sampling schedules is reported in $\mathrm{Hu}$ [25].

Andersen six-stage samplers (Tisch 1 ACFM Six-stage Viable Particle Sampler, Tisch Environmental, Inc., Village of Cleves, $\mathrm{OH}$.) were used for the field bacteria and fungi sampling. To ensure the performance of the viable samplers, the samplers' flow rates were calibrated to the design flow rate at $28.31 \cdot \mathrm{min}^{-1}$ before each sampling event, and were checked after sampling using a digital flow meter, Bios DryCal Defender 510-H (0.3 - 30 LPM) (Bios International Corporation, Butler, NJ). Sampling duration at all ambient locations was set for 10 


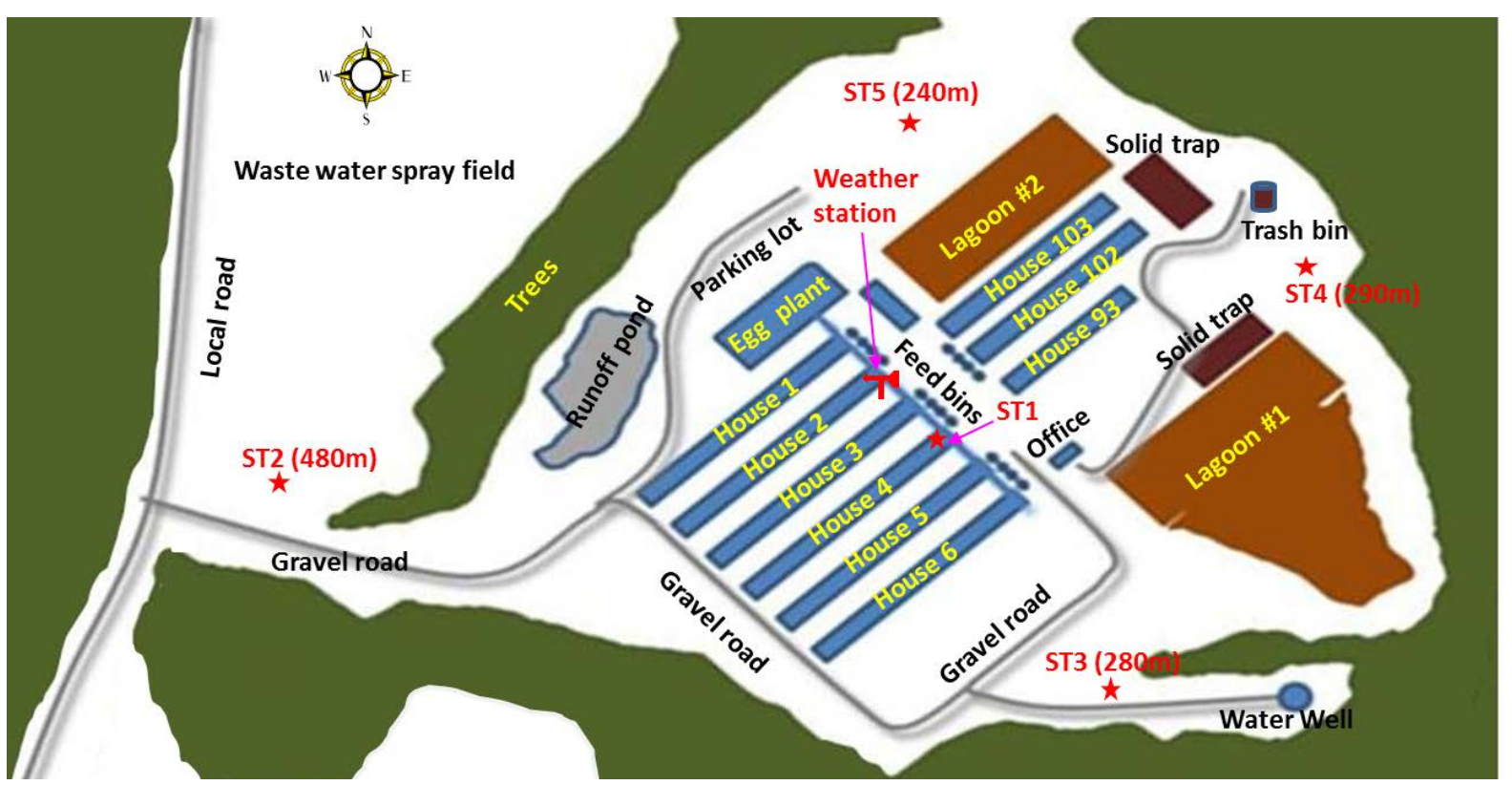

Figure 1. The layer farm layout and the bioaerosol sampling stations [24].

Table 1. Bioaerosol sampling events and sample sizes (plates)*.

\begin{tabular}{ccccccc} 
& \multicolumn{2}{c}{ Winter (5 days) } & \multicolumn{2}{c}{ Spring (4 days) } & \multicolumn{2}{c}{ Summer (5 days) } \\
\cline { 2 - 7 } & Source & Ambient & Source & Ambient & Source & Ambient \\
\hline Bacteria & 180 & 360 & 144 & 288 & 180 & 360 \\
Fungi & 180 & 360 & 144 & 282 & 180 & 360 \\
\hline
\end{tabular}

*Sample sizes (plates) are the products of [sampling day $\times$ test/day $\times 6$ plates/test].

min per test for both bacteria and fungi samples without encountering any overloading issues.

The collection media for total bacteria was R2A agar, which is a non-selective agar that has been found to allow the culturing of many species of bacteria. The collection media for total fungi was Malt Extract Agar (MEA), which is commonly used for the isolation of fungi. To prevent bacteria growth on MEA agar, $1 \mathrm{ml}$ $1000 \times$ streptomycin sulfate was added to each 1 L MEA agar after cooling and before dispensing. The final concentration of streptomycin sulfate in the plates was $0.1 \%$. The prepared agar plates were labeled and stored at $4^{\circ} \mathrm{C}$ until use to avoid background contamination.

As a quality control/quality assurance (QA/QC) procedure, a set of lab and field blanks for both collection media, R2A and MEA, were used on each sampling date. They were randomly chosen from the prepared plates before each sampling event. The lab blanks were stored in the refrigerator in the lab where the agar plates were prepared. The filed blanks were transported to the sampling site with other sampling plates in coolers at each sampling event. The blanks were settled without covers being removed and were incubated with all other sampled plates after sampling.

After each sampling event, the bacteria and fungi samples collected at the farm were transported back to the lab on the same day in coolers with ice packs. The samples were then incubated immediately after arrival in the lab under consistent temperatures to allow the colonies to grow. Bacteria samples were incubated for 48 hours at $30^{\circ} \mathrm{C}$, and fungi samples were incubated for 72 hours at $25^{\circ} \mathrm{C}$ [26]. After incubation, colony counting was conducted under magnification and with the aid of a colony counter (Quebec Darkfield Manual Colony Counter, Reichert, Inc.). More details about bioaerosol sampling and analysis methods may be found in $\mathrm{Hu}$ [25] and $\mathrm{Hu}$ et al. [27].

After the plate reading, bacterial or fungal concentration (C) in $\mathrm{CFU} \mathrm{m}^{-3}$ was calculated using the following equation [25] [27]: 


$$
\mathrm{C}=\frac{\mathrm{CFU}}{\mathrm{t} \times \mathrm{Q}_{\mathrm{s}}}
$$

where, CFU is the colony forming unit, which indicates the numbers of total bacteria or fungi counts on the sampled plate; $t$ is sampling duration; and $\mathrm{Q}_{\mathrm{s}}$ is sampler flow rate, the average value of pre-sampling flow rate and post-sampling flow rate.

Bacterial and fungal emission rates were calculated based upon measured in-house concentrations and the house ventilation rate. Often times, higher ventilation rate in hot weather led to higher emission rates. Detailed information about emission rate calculation and emission rate results is reported in $\mathrm{Hu}$, et al. [27].

In total, 1512 non-selective bacterial sample plates and 1326 non-selective fungal sample plates were collected and analyzed over 3 seasons (winter, spring, and summer) at all four ambient stations to examine temporal and spatial variations on ambient bioaerosols concentrations under different meteorological conditions. ANOVA tests were applied to test the seasonal, time, and spatial variations of bioaerosol concentrations in the vicinity. Statistical analysis was applied to identify the significant influencing factors affecting ambient bacterial and fungal concentrations. Temperature, $\mathrm{RH}$, wind vector (i.e., wind speed/direction), solar radiation, and emission rate were used as the five indicators to predict downwind bacterial and fungal concentrations in the vicinity. Statistical model was developed and selected through the following steps:

1) Plotted the relationship between the log-transformed downwind bioaerosol concentrations and each of the influencing factors.

2) Based on the relationship shown in the plotting, introduced transformed influencing factors as potential significant predictors.

3) Developed all possible regression models.

4) Model with the largest R-square and the smallest $\mathrm{C}(\mathrm{p})$ value was selected as the best predicting model.

All the statistical analyses were conducted using SAS9.2 software (SAS Institute, Inc., Cary, NC).

\section{Results and Discussion}

\subsection{Seasonal Effects}

The mean concentrations of bacteria and fungi for all ambient stations (ST2-ST5) were computed by season. The mean concentrations \pm SDs of bacteria were $869 \pm 1003 \mathrm{CFU} \mathrm{m}^{-3}, 1263 \pm 1955 \mathrm{CFU} \mathrm{m}^{-3}$, and $1193 \pm 1497$ $\mathrm{CFU} \mathrm{m}{ }^{-3}$ for winter, spring and summer, respectively. An ANOVA test indicates that there was no significant difference in ambient bacterial concentrations among three seasons $(p=0.33)$. The mean concentrations \pm SDs of fungi were $280 \pm 373 \mathrm{CFU} \mathrm{m}^{-3}, 1403 \pm 1461 \mathrm{CFU} \mathrm{m}^{-3}$, and $2558 \pm 2276 \mathrm{CFU} \mathrm{m}{ }^{-3}$ for winter, spring and summer, respectively. Mean ambient fungal concentrations were the highest in summer and the lowest in winter $(p<0.0001)$.

The lowest fungal concentration in winter may be due to the inactivation of fungi at low temperature and $\mathrm{RH}$ levels. Fungal concentrations were higher in summer than in spring although solar radiations were significantly higher in summer than in spring $(p<0.0001)$. Bacterial concentrations did not vary with season although atmospheric conditions changed significantly (Table 2).

Bacterial and fungal concentrations at each ambient station were averaged by season to illustrate the seasonal effects at different stations. Table 3 and Table 4 show the mean values of bacterial and fungal concentrations at four ambient stations (ST2-ST5) in three seasons (winter, spring and summer). As shown in these tables, seasonal variations of bacterial concentrations varied at ambient stations. At ST2 and ST5, bacterial concentrations were the highest in spring and the lowest in winter, while at ST3 and ST4, bacterial concentrations were the lowest in spring and higher in winter and summer. This observation may suggest that wind played an important role in affecting ambient airborne bacterial concentration because there was significant difference $(p<0.0001)$ between concentrations at downwind locations and upwind locations. Unlike bacterial, fungal concentrations showed coincident pattern of seasonal variations at all four ambient stations. Fungal concentrations were the lowest in winter and increased from winter to summer.

\subsection{Time of Day Effects}

Ambient temperature and RH changed not only with season, but also with time of day on each sampling day. In 
Table 2. Meteorological data in the vicinity in three seasons.

\begin{tabular}{ccccccc}
\hline \multirow{2}{*}{ Season } & \multicolumn{2}{c}{${\operatorname{Temperature~}\left({ }^{\circ} \mathrm{C}\right)}^{2}$} & \multicolumn{2}{c}{ RH (\%) } & \multicolumn{2}{c}{ Solar Radiation $\left(\mathrm{W} / \mathrm{m}^{2}\right)$} \\
\cline { 2 - 7 } & Mean $^{*}$ & SD & Mean & SD & Mean & SD \\
Winter & 5 & 4 & 39 & 15 & 366 & 156 \\
Spring & 15 & 5 & 62 & 13 & 454 & 218 \\
Summer & 34 & 3 & 54 & 11 & 783 & 189 \\
\hline
\end{tabular}

"Mean of 166 measurement points.

Table 3. Mean concentrations (CFU m ${ }^{-3}$ ) and SDs of bacteria at ambient stations in three seasons*.

\begin{tabular}{ccccc}
\hline Season & Sampling Location & Mean & SD & N \\
\hline \multirow{3}{*}{ Winter } & ST2 & 377 & 533 & 15 \\
& ST3 & 1525 & 1039 & 15 \\
& ST4 & 1484 & 77 & 15 \\
& ST5 & 91 & 2257 & 15 \\
ST2 & 2827 & 1013 & 9 \\
Spring & ST3 & 555 & 75 & 15 \\
& ST4 & 100 & 2329 & 15 \\
& ST5 & 1456 & 1034 & 14 \\
& ST2 & 761 & 1995 & 15 \\
\hline
\end{tabular}

"From the two-way ANOVA test, it is shown that the weather and location were not significant ( $p=0.46$ and 0.25 , respectively), but the interaction between them was significant $(p=1.83 \mathrm{E}-8)$.

Table 4. Mean concentrations (CFU m ${ }^{-3}$ ) and SDs of fungi at ambient stations in three seasons*.

\begin{tabular}{ccccc}
\hline Season & Sampling Location & Mean & SD & N \\
\hline \multirow{3}{*}{ Winter } & ST2 & 611 & 623 & 15 \\
& ST3 & 213 & 146 & 15 \\
& ST4 & 163 & 61 & 15 \\
& ST5 & 132 & 708 & 11 \\
Spring & ST2 & 1205 & 2305 & 15 \\
& ST3 & 1550 & 1068 & 9 \\
& ST4 & 1617 & 864 & 12 \\
& ST5 & 1241 & 1558 & 15 \\
& ST2 & 2510 & 1368 & 15 \\
& ST3 & 2889 & 842 & 3862 \\
& ST4 & 1515 & 3317 & 15 \\
\hline
\end{tabular}

*From the two-way ANOVA test, it is shown that the weather was significant $(p=3.28 \mathrm{E}-13)$, while the location and the interaction between them were not significant ( $p=0.43$ and 0.10 , respectively). 
order to estimate the time effect on ambient bioaerosol concentrations in different seasons, mean concentrations of bacteria and fungi at different times of day were computed by season. Table 5 and Table 6 list the mean concentrations of bacteria and fungi at ambient locations (ST2-5) in three seasons at different times of day. In winter, due to the low temperature and $\mathrm{RH}$, concentrations of bacteria and fungi were low and changed only

Table 5. Ambient bacterial concentrations (CFU m ${ }^{-3}$ ) and SDs at different times of day separated by season.

\begin{tabular}{|c|c|c|c|c|}
\hline Season & Time of Day & Mean & SD & $\mathrm{N}$ \\
\hline \multirow{6}{*}{ Winter } & 10:00 AM & 869 & 860 & 10 \\
\hline & 10:30 AM & 818 & 1146 & 10 \\
\hline & $11: 00 \mathrm{AM}$ & 781 & 878 & 10 \\
\hline & 1:00 PM & 955 & 1138 & 10 \\
\hline & 1:30 PM & 972 & 1131 & 10 \\
\hline & 2:00 PM & 819 & 1075 & 10 \\
\hline \multirow{6}{*}{ Spring } & 10:00 AM & 1410 & 2002 & 8 \\
\hline & $10: 30 \mathrm{AM}$ & 1372 & 2480 & 8 \\
\hline & $11: 00 \mathrm{AM}$ & 2014 & 2636 & 8 \\
\hline & 1:00 PM & 1360 & 2280 & 8 \\
\hline & 1:30 PM & 702 & 1015 & 8 \\
\hline & 2:00 PM & 720 & 966 & 8 \\
\hline \multirow{6}{*}{ Summer } & $10: 00 \mathrm{AM}$ & 1296 & 1651 & 10 \\
\hline & 10:30 AM & 777 & 1161 & 10 \\
\hline & $11: 00 \mathrm{AM}$ & 898 & 1138 & 10 \\
\hline & 1:00 PM & 1119 & 1185 & 9 \\
\hline & 1:30 PM & 1361 & 1345 & 10 \\
\hline & 2:00 PM & 1702 & 2320 & 10 \\
\hline
\end{tabular}

${ }^{*}$ Mean was calculated using measured concentrations at all four ambient stations. ${ }^{* *}$ From the two-way ANOVA test, it is shown that the time, weather, and the interaction were not significant ( $p=0.99,0.30$, and 0.66 , respectively).

Table 6. Ambient fungal concentrations (CFU m ${ }^{-3}$ ) and SDs at different times of day separated by season.

\begin{tabular}{|c|c|c|c|c|}
\hline Season & Time of day & Mean* & SD & $\mathrm{N}$ \\
\hline \multirow{6}{*}{ Winter } & 10:00 AM & 453 & 575 & 10 \\
\hline & 10:30 AM & 317 & 489 & 10 \\
\hline & 11:00 AM & 341 & 484 & 10 \\
\hline & 1:00 PM & 217 & 121 & 10 \\
\hline & 1:30 PM & 168 & 66 & 10 \\
\hline & 2:00 PM & 167 & 104 & 10 \\
\hline \multirow{6}{*}{ Spring } & 10:00 AM & 1099 & 512 & 8 \\
\hline & 10:30 AM & 2307 & 3063 & 8 \\
\hline & 11:00 AM & 1131 & 598 & 8 \\
\hline & 1:00 PM & 914 & 489 & 8 \\
\hline & 1:30 PM & 1140 & 600 & 8 \\
\hline & 2:00 PM & 2295 & 1403 & 8 \\
\hline \multirow{6}{*}{ Summer } & 10:00 AM & 2596 & 1444 & 10 \\
\hline & 10:30 AM & 2368 & 1181 & 10 \\
\hline & 11:00 AM & 1812 & 1083 & 10 \\
\hline & 1:00 PM & 2009 & 1150 & 9 \\
\hline & 1:30 PM & 2705 & 2724 & 10 \\
\hline & 2:00 PM & 3558 & 4317 & 10 \\
\hline
\end{tabular}

*Mean was calculated using measured concentrations at all four ambient stations. ${ }^{* *}$ From the two-way ANOVA test, it is shown that the weather was significant $(p=2.44 \mathrm{E}-12)$, while the time and the interaction between them were not significant $(p=0.14$ and 0.57 , respectively). 
slightly during the day. In spring, there was no consistent pattern observed for both bacteria and fungi. Bacteria concentrations were the lowest in afternoon, while fungi concentrations were the lowest in early morning and at noon. In summer, bacteria and fungi variations showed a similar pattern.

To investigate diurnal time effects on bacterial and fungal concentrations at different locations, mean concentrations of bacteria and fungi at different times of day were calculated by station. Table 7 and Table 8 show the time of day effects at different ambient stations. Bacterial and fungal concentrations over time varied greatly at different stations. At ST2 and ST3, bacterial concentrations were higher in the afternoons than mornings. At ST4 and ST5, bacterial concentrations were higher in the mornings than afternoons. At ST2 and ST4, fungal concentration decreased from morning to afternoon. At ST3, fungal concentrations were the highest at noon. At ST5, fungal concentrations were the lowest at noon. Bacterial and fungal concentrations displayed variations with time at different stations, which was mainly because of the spatial effects.

\subsection{Spatial Variation}

To investigate spatial effects, data were grouped into the upwind and downwind classes. The overall mean concentrations of bacteria and fungi at downwind locations were $1856 \pm 1688 \mathrm{CFU} \mathrm{m}{ }^{-3}$ and $1155 \pm 1179 \mathrm{CFU} \mathrm{m}^{-3}$, respectively. The overall mean concentrations of bacteria and fungi at upwind locations were $291 \pm 606 \mathrm{CFU}$ $\mathrm{m}^{-3}$ and $1690 \pm 2321 \mathrm{CFU} \mathrm{m}{ }^{-3}$, respectively. Mean concentration of bacteria was significantly higher downwind than upwind $(p<0.0001)$. In contrast, mean concentration of fungi at downwind was not significantly different from upwind $(p=0.1206)$. This observation indicated that wind vector (i.e., combined effects of wind direction

Table 7. Ambient bacterial concentrations $\left(\mathrm{CFU} \mathrm{m}{ }^{-3}\right)$ and SDs at different times of day separated by station.

\begin{tabular}{|c|c|c|c|c|}
\hline Station & Time of Day & Mean ${ }^{*}$ & SD & $\mathrm{N}$ \\
\hline \multirow{6}{*}{ ST2 } & 10:00 AM & 1300 & 1868 & 8 \\
\hline & 10:30 AM & 709 & 1296 & 8 \\
\hline & 11:00 AM & 1116 & 1929 & 8 \\
\hline & 1:00 PM & 2184 & 2234 & 6 \\
\hline & 1:30 PM & 1273 & 874 & 6 \\
\hline & 2:00 PM & 876 & 965 & 6 \\
\hline \multirow{6}{*}{ ST3 } & 10:00 AM & 1121 & 949 & 7 \\
\hline & 10:30 AM & 350 & 291 & 7 \\
\hline & 11:00 AM & 1371 & 1242 & 7 \\
\hline & 1:00 PM & 1247 & 1530 & 8 \\
\hline & 1:30 PM & 863 & 1076 & 7 \\
\hline & 2:00 PM & 1612 & 2152 & 8 \\
\hline \multirow{6}{*}{ ST4 } & 10:00 AM & 1592 & 1551 & 7 \\
\hline & 10:30 AM & 1675 & 1457 & 7 \\
\hline & 11:00 AM & 1068 & 1058 & 7 \\
\hline & 1:00 PM & 1153 & 1061 & 6 \\
\hline & 1:30 PM & 990 & 832 & 6 \\
\hline & 2:00 PM & 836 & 788 & 6 \\
\hline \multirow{6}{*}{ ST5 } & 10:00 AM & 590 & 1025 & 6 \\
\hline & 10:30 AM & 1179 & 2346 & 6 \\
\hline & 11:00 AM & 1150 & 2096 & 6 \\
\hline & 1:00 PM & 556 & 616 & 8 \\
\hline & 1:30 PM & 674 & 1125 & 8 \\
\hline & 2:00 PM & 975 & 1645 & 8 \\
\hline
\end{tabular}

${ }^{*}$ Mean was calculated using measured concentrations over three seasons at any given station stations. ${ }^{* *}$ From the two-way ANOVA test, it is shown that the time, weather, and the interaction between them were not significant ( $p=0.94,0.53$, and 0.72 , respectively). 
Table 8. Ambient fungal concentrations $\left(\mathrm{CFU} \mathrm{m}{ }^{-3}\right)$ and SDs at different times of day separated by station.

\begin{tabular}{|c|c|c|c|c|}
\hline Station & Time of Day & Mean ${ }^{*}$ & SD & $\mathrm{N}$ \\
\hline \multirow{6}{*}{ ST2 } & 10:00 AM & 1713 & 1268 & 8 \\
\hline & 10:30 AM & 1799 & 1896 & 8 \\
\hline & 11:00 AM & 1369 & 1090 & 8 \\
\hline & 1:00 PM & 1799 & 1896 & 8 \\
\hline & 1:30 PM & 1369 & 1090 & 8 \\
\hline & 2:00 PM & 725 & 516 & 8 \\
\hline \multirow{6}{*}{ ST3 } & 10:00 AM & 1394 & 1301 & 7 \\
\hline & 10:30 AM & 1177 & 1051 & 7 \\
\hline & 11:00 AM & 2524 & 3369 & 7 \\
\hline & 1:00 PM & 1273 & 1441 & 8 \\
\hline & 1:30 PM & 1452 & 1864 & 8 \\
\hline & 2:00 PM & 1539 & 1788 & 8 \\
\hline \multirow{6}{*}{ ST4 } & 10:00 AM & 1064 & 863 & 7 \\
\hline & 10:30 AM & 1210 & 1361 & 7 \\
\hline & 11:00 AM & 917 & 828 & 7 \\
\hline & 1:00 PM & 770 & 477 & 7 \\
\hline & 1:30 PM & 694 & 488 & 6 \\
\hline & 2:00 PM & 1435 & 1596 & 6 \\
\hline \multirow{6}{*}{ ST5 } & 10:00 AM & 1181 & 1190 & 6 \\
\hline & 10:30 AM & 1564 & 1716 & 6 \\
\hline & 11:00 AM & 1135 & 1222 & 6 \\
\hline & 1:00 PM & 1025 & 1001 & 8 \\
\hline & 1:30 PM & 1888 & 2967 & 8 \\
\hline & 2:00 PM & 2506 & 5142 & 8 \\
\hline
\end{tabular}

*Mean was calculated using measured concentrations over three seasons at any given station stations. ${ }^{* *}$ From the two-way ANOVA test, it is shown that the time, weather, and the interaction between them were not significant ( $p=0.94,0.53$, and 0.72 , respectively).

and wind speed) played an important role in affecting bacterial and fungal concentrations in the vicinity of the farm.

The overall mean concentrations of bacteria and fungi at downwind locations were computed by season. Table 9 shows concentrations of bacteria and fungi at downwind location in three seasons. Downwind concentrations of bacteria were not significantly different in three seasons $(p=0.51)$. Fungi concentration at downwind were the highest in summer and the lowest in winter $(p<0.0001)$. The variations in downwind bacterial and fungal concentrations followed the same patterns as the overall mean bacterial and fungal concentrations in the vicinity of the farm did.

The average downwind and upwind concentrations of bacteria and fungi at each ambient station were calculated to illustrate the spatial variation of their concentrations at different locations (Table 10). Mean concentrations of bacteria at each station were higher downwind than upwind (ST2: $p=0.0005$, ST3: $p=0.0004$, ST4: $p=0.0002$, ST5: $p=0.0016$ ), which was in agreement with the variations of overall mean ambient bacteria concentration. The mean concentrations of downwind bacteria at four ambient stations were not significantly different $(p=0.70)$. Similarly, there was no significant difference among the mean concentrations of upwind bacteria at four ambient stations $(p=0.36)$. In contrast, there were no significant differences between upwind and downwind fungi concentration at any station but ST3 (ST2: $p=0.64$, ST3: $p=0.0019$, ST4: $p=0.15$, ST5: $p=0.92$ ). This observation suggests that wind direction and speed seemed to have lower impact on fungal concentration variations than bacteria. The mean concentrations of downwind fungi at ST5 and ST2 were higher than those at ST3 and ST4 $(p=0.03)$. The mean concentrations of upwind fungi at four ambient stations were 
Table 9. Bacterial and fungal concentrations $\left(\mathrm{CFU} \mathrm{m}^{-3}\right)$ and SDs at downwind separated by season.

\begin{tabular}{|c|c|c|c|}
\hline Season & Mean ${ }^{*}$ & SD & $\mathrm{N}$ \\
\hline \multicolumn{4}{|c|}{ Bacteria } \\
\hline Winter & $1629^{\mathrm{a}}$ & 916 & 30 \\
\hline Spring & $2421^{\mathrm{a}}$ & 2235 & 24 \\
\hline Summer & $1732^{\mathrm{a}}$ & 1748 & 30 \\
\hline \multicolumn{4}{|c|}{ Fungi } \\
\hline Winter & $185^{\mathrm{b}}$ & 130 & 30 \\
\hline Spring & $1131^{\mathrm{c}}$ & 803.7631 & 25 \\
\hline Summer & $2113^{d}$ & 1346.257 & 31 \\
\hline
\end{tabular}

*Means with the same letter are not significantly different.

Table 10. Concentrations of bacteria \& fungi $\left(\mathrm{CFU} \mathrm{m}{ }^{-3}\right)$ at ambient stations under downwind \& upwind conditions.

\begin{tabular}{|c|c|c|c|c|c|c|c|c|c|c|c|c|}
\hline \multirow{3}{*}{ Location } & \multicolumn{6}{|c|}{ Bacteria } & \multicolumn{6}{|c|}{ Fungi } \\
\hline & \multicolumn{3}{|c|}{ Downwind } & \multicolumn{3}{|c|}{ Upwind } & \multicolumn{3}{|c|}{ Downwind } & \multicolumn{3}{|c|}{ Upwind } \\
\hline & Mean $^{*}$ & SD & $\mathrm{N}$ & Mean & SD & $\mathrm{N}$ & Mean & SD & $\mathrm{N}$ & Mean & SD & $\mathrm{N}$ \\
\hline ST2 & $2223^{\mathrm{b}}$ & 2045 & 18 & $457^{\mathrm{a}}$ & 850 & 24 & $1585^{\mathrm{c}, \mathrm{d}}$ & 1278 & 17 & $1393^{d}$ & 1390 & 24 \\
\hline ST3 & $1737^{\mathrm{b}}$ & 1547 & 25 & $284^{\mathrm{a}}$ & 685 & 19 & $870^{c}$ & 1421 & 27 & $2727^{\mathrm{d}}$ & 2022 & 18 \\
\hline ST4 & $1911^{\mathrm{b}}$ & 1175 & 26 & $266^{\mathrm{a}}$ & 370 & 13 & $776^{\mathrm{cd} d}$ & 591 & 23 & $1368^{\mathrm{d}}$ & 997 & 15 \\
\hline ST5 & $1611^{\mathrm{b}}$ & 2042 & 20 & $133^{\mathrm{a}}$ & 224 & 22 & $1636^{\mathrm{c,d}}$ & 969 & 19 & $1685^{d}$ & 3574 & 23 \\
\hline
\end{tabular}

*Means with the same letter are not significantly different.

not significantly different $(p=0.28)$. The variations might be mainly because of the location of each station. As shown in Figure 1, ST2 was the furthest away from the production houses and close to a local road and a waste water spray field. There was also a line of trees between ST2 and the houses that might block transport of bioaerosol from the production houses to ST2. However, ST2 had a higher mean value of fungi downwind concentration. It was probably that the spray field, instead of the farm, was the largest source of fungi for ST2. ST3 was very close to the cross-ventilated house (House 6), and the fans of house 6 could blow bioaerosols directly toward ST3. ST4 was close to a large waste treatment lagoon. ST5 was further away from the production houses than ST3 and ST4. In addition, there was an egg packing plant located between the production houses and ST5. However, upwind bacteria and upwind fungi concentrations at ST5 were not lower than other ambient stations, and downwind fungi concentrations were even higher than ST3 and ST4. There might be other source of airborne fungi that had impact on bioaerosol concentrations at ST5. The upwind concentrations should be considered the concentrations that were impacted by the sources other than the house emissions.

\subsection{Influencing Factors}

In comparison to bacterial and fungal concentrations at source (ST1), there were more factors affecting the concentrations at ambient stations in the vicinity of the farm. While various meteorological variables and emission rate were selected to examine their impact on downwind concentrations, distance from the source was not due to lack of resource and accessibility to the neighboring properties. By all means this fact should be included in future studies of fate and transport of bioaerosols.

Figure 2 and Figure 3 illustrate the impacts of meteorological factors and emission rate on ambient bacterial and fungal concentrations at downwind locations.

As shown in Figure 2, no obvious linear relationships between downwind bacterial concentrations and air temperature (Figure 2(a)), RH (Figure 2(b)), or solar radiation (Figure 2(d)) were observed from the plots. High concentrations of bacteria were more likely to be detected at temperatures from $20^{\circ} \mathrm{C}$ to $40^{\circ} \mathrm{C}$; medium to high RH levels (40\% to $80 \%$ ) resulted in higher bacterial concentrations. Higher concentrations of bacteria were detected with moderate to strong solar radiation $\left(>300 \mathrm{~W} / \mathrm{m}^{2}\right)$. Bacterial concentrations were observed to be positively related to wind vector (W) (Figure 2(c)) and emission rate (Figure 2(e)). On the other hand, downwind 

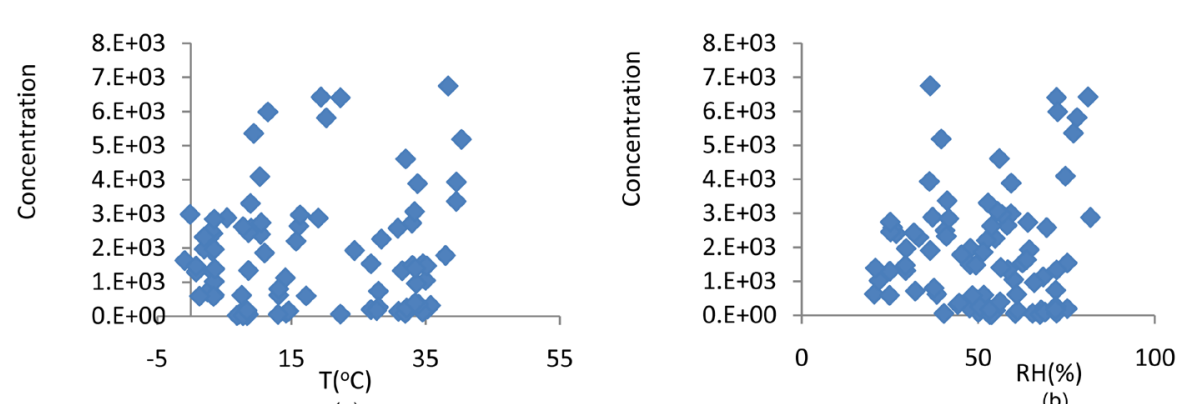

(b)

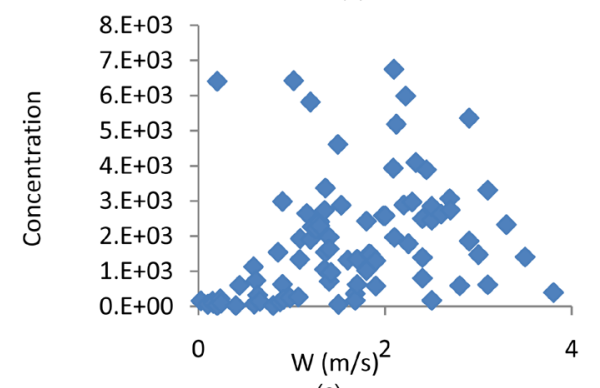

(c)

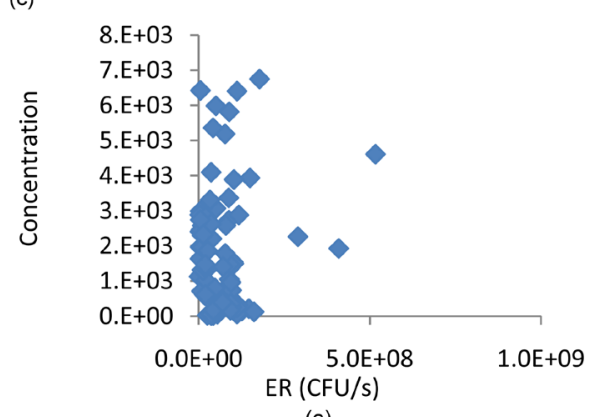

(e)

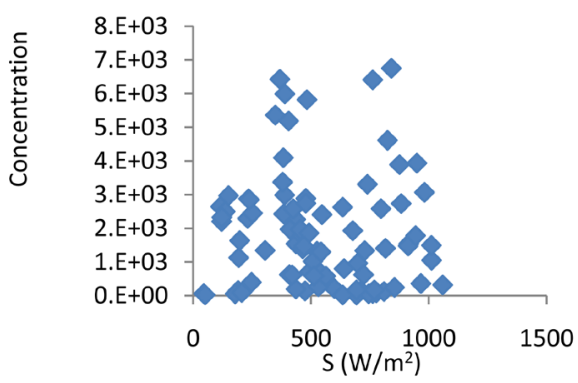

(d)

Figure 2. Responses of downwind bacterial concentrations (CFU $\mathrm{m}^{-3}$ ) to various influencing factors: $(\mathrm{a})=$ temperature $(\mathrm{T}),(\mathrm{b})=\mathrm{RH},(\mathrm{c})=$ wind vector $(\mathrm{W}),(\mathrm{d})=$ solar radiation $(\mathrm{S}),(\mathrm{e})=$ emission rate (ER).

fungal concentrations were positively related to T, RH, solar radiation, and emission rate (Figure 3(a), Figure 3(b), Figure 3(d)), and were negatively related to wind vector (W) (Figure 3(c)). Both bacterial and fungal concentrations were found to be higher at stronger solar radiation (Figure 2(d), Figure 3(d)), although solar radiation was reported to cause bioaerosol damage [15]. This might be because that strong solar radiation with low wind speed $(<5 \mathrm{~m} / \mathrm{s})$ resulted in unstable to very unstable atmosphere, and the consequent unstable atmosphere caused high bacterial and fungal concentrations at local downwind locations $(<2 \mathrm{~km}$ away from the sources).

For bacterial concentration analysis, the linear regression analysis suggests that downwind bacterial concentration was only linearly dependent on wind vector, $\mathrm{W}(p=0.0046)$ at a significant level of 0.05 . However, it did not mean that other influencing factors (i.e., T, RH, solar radiation, and emission rate) were not important in impacting downwind bacterial concentration, because there were strong linear dependencies between them. Tests of the linear dependencies between the six variables indicate that $\mathrm{T}$ had significant linear dependencies with RH $(p=0.0022)$, solar radiation $(p<0.0001)$, and emission rate $(p<0.0001)$; RH had significant linear dependencies with $\mathrm{T}$, wind vector $\mathrm{W}(p=0.0022)$, and emission rate $(p=0.0169)$; wind vector $\mathrm{W}$ had significant linear dependencies with RH; solar radiation had significant linear dependencies with $\mathrm{T}$ and emission rate $(p=0.0002)$; and emission rate had significant linear dependencies with $\mathrm{T}, \mathrm{RH}$, and solar radiation.

For fungal concentration analysis, Pearson correlation coefficients suggested that downwind fungal concentration was significantly linearly dependent on all five influencing factors at a 0.05 level. Similarly, there were strong linear dependencies between the influencing factors. Temperature had significant linear dependencies 


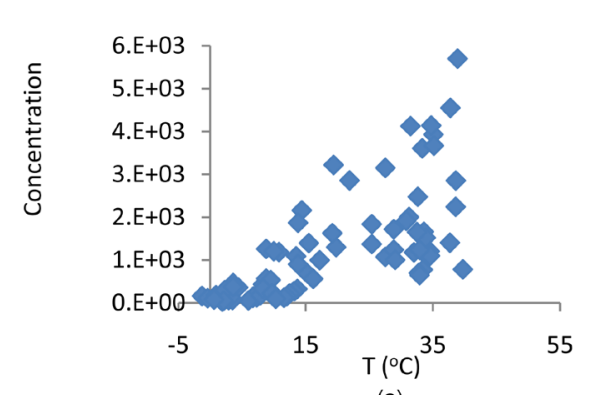

(a)

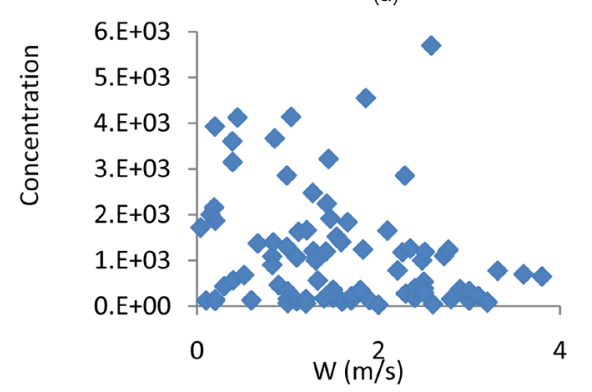

(c)

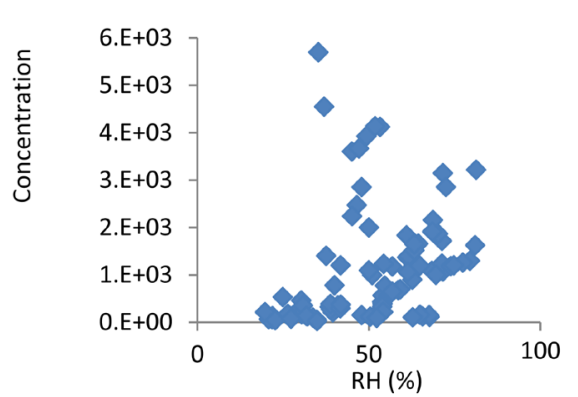

(b)

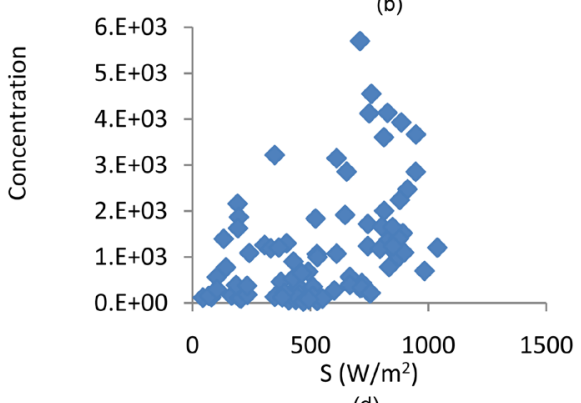

(d)

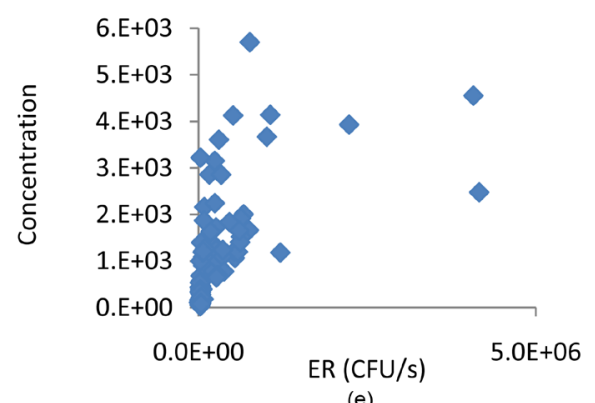

(e)

Figure 3. Responses of downwind fungal concentrations $\left(\mathrm{CFU} \mathrm{\textrm {m } ^ { - 3 }}\right)$ to various influencing factors: (a) = temperature (T), (b) = RH, (c) = wind vector $(\mathrm{W}),(\mathrm{d})=$ solar radiation $(\mathrm{S}),(\mathrm{e})=$ emission rate (ER).

with RH ( $p=0.0062)$, solar radiation $(p<0.0001)$, and emission rate $(p<0.0001)$; RH had significant linear dependencies with $\mathrm{T}$ and wind vector, $\mathrm{W}(p=0.0488)$; wind vector $\mathrm{W}$ had significant linear dependencies with $\mathrm{RH}$; solar radiation had significant linear dependencies with $\mathrm{T}$ and emission rate $(p<0.0001)$; and emission rate had significant linear dependencies with $\mathrm{T}$ and solar radiation.

The linear correlation between variables might cause some predictors to be not important when fitted in a linear regression model. To better study the impacts of influencing factors on downwind bacterial and fungal concentrations, log transformed bacterial and fungal concentrations were used as new responses. As suggested by residual plots (not shown), emission rate was also log transformed. Quadratic forms of wind vector $\left(\mathrm{W}^{2}\right)$ and emission rate (emission ${ }^{2}$ ) were introduced as two new predictors for predicting downwind bacterial concentration. Among all subset models, the model included $\mathrm{T}, \mathrm{W}, \mathrm{W}^{2}$, solar radiation, emission rate, and emission ${ }^{2}$ was preferred by R-square and Mallow's CP selections. For predicting downwind fungal concentration, residual plots suggested that the relationships between fungal downwind concentration and emission or wind vector (W) were not quadratic. Among all subset models, the model included every influencing factor but solar radiation was preferred by R-square and Mallow's CP selections. Table 11 lists the results of the selective regression models. As shown in this table, wind vector, $\mathrm{W}$ had different effects on bacterial and fungal concentrations. On the one hand, high speed wind might bring more bacteria and fungi to a sampling station more quickly; on the other hand, strong wind might also cause damage to bacteria and fungi. Therefore, increasing wind vector resulted in increasing in bacterial concentrations and decreasing in fungal concentrations. For the influencing factors that were not included in the regression models, it does not mean that they were not important. The results 
Table 11. Selected models for downwind bacterial and fungal concentration prediction.

\begin{tabular}{ccccc}
\hline & Estimate & Std. Error & $p$-Value \\
\hline Intercept & 56 & 19 & 0.0040 \\
Bacteria $^{*}$ & $\mathrm{~T}$ & 0.034 & 0.016 & 0.037 \\
& $\mathrm{~W}$ & 3.0 & 0.46 & $<0.0001$ \\
& $\mathrm{~W}^{2}$ & -0.62 & 0.13 & $<0.0001$ \\
& Solar Radiation & -0.0016 & 0.00058 & 0.0064 \\
& Emission Rate & -6.0 & 2.3 & 0.0099 \\
Emission & & 0.17 & 0.067 & 0.0131 \\
Intercept $^{2}$ & 2.0 & 1.1 & 0.060 \\
$\mathrm{~T}$ & 0.045 & 0.013 & 0.0006 \\
$\mathrm{RH}$ & 0.021 & 0.0047 & $<0.0001$ \\
$\mathrm{~W}$ & -0.19 & 0.24 & 0.078 & 0.0187 \\
\hline
\end{tabular}

"Model DF $=6$, total $\mathrm{DF}=85, \mathrm{R}^{2}=0.5221 ;{ }^{* *}$ Model $\mathrm{DF}=4$, total $\mathrm{DF}=85, \mathrm{R}^{2}=0.7481$.

of the models only indicated that when other factors were controlled, RH was no longer an important predictor of bacterial concentration downwind while solar radiation was no longer an important predictor of fungal concentration downwind. Due to the differences in size and specie characteristics, bacteria and fungi responded differently to the influencing factors. Temperature, wind vector, and emission rate were important predictors for both bacterial and fungal variations.

\section{Conclusion}

In this project, concentrations of non-selective bacteria and fungi were measured using Andersen six-stage sampler in the vicinity (4 stations) of an AFO facility for three seasons. Mean concentrations of ambient bacteria and fungi ranged from $8.7 \times 10^{2} \mathrm{CFU} \mathrm{m}{ }^{-3}$ to $1.3 \times 10^{3} \mathrm{CFU} \mathrm{m}^{-3}$ and from $2.8 \times 10^{2} \mathrm{CFU} \mathrm{m}^{-3}$ to $1.4 \times 10^{3} \mathrm{CFU}$ $\mathrm{m}^{-3}$, respectively. Ambient bacterial concentrations did not vary with season although atmospheric conditions changed significantly. The lowest ambient fungal concentration was observed in winter time. Ambient fungal concentrations were higher in summer than in spring although solar radiation was significantly higher in summer. There were significant differences between downwind and upwind bacterial and fungal concentrations. Downwind bacterial and fungal concentrations responded differently to the influencing factors. Bacteria concentrations were quadratic in response to wind vector and emission rate, positively correlated with temperature, and negatively correlated with solar radiation. Fungal concentrations were positively correlated with temperature, $\mathrm{RH}$, and emission rate, and were negatively correlated with wind vector.

\section{Acknowledgements}

This project was supported in part by the NSF CAREER Award No. CBET-0954673 and USDA NRI Grant No. 2008-35112-18757. Help from Qianfeng Li and Manqing Ying for field sampling is also thankfully acknowledged. Authors would also like to thank the egg production farm for their generous support.

\section{References}

[1] Wang-Li, L., Li, Q. and Byfield, G.E. (2013) Identifications of Bioaerosols Released from an Egg Production Facility in Southeast U.S. Journal of Environmental Engineering Science, 30, 2-10. http://dx.doi.org/10.1089/ees.2011.0517

[2] Green, C.F., Gibbs, S.G., Tarwater, P.M., Mota, L.C. and Scarpino, P.V. (2006) Bacterial Plume Emanating from the Air Surrounding Swine Confinement Operations. Journal of Occupational and Environmental Hygiene, 3, 9-15. http://dx.doi.org/10.1080/15459620500430615

[3] Scarpino, P.V. and Quinn, H. (1998) Bioaerosol Distribution Patterns Adjacent to Two Swine-Growing-Finishing 
Housed Confinement Units in the American Midwest. Journal of Aerosol Science, 29, 553-554. http://dx.doi.org/10.1016/S0021-8502(98)00289-4

[4] Dungan, R.S., Leytem, A.B., Verwey, S.A. and Bjorneberg, D.L. (2010) Assessment of Bioaerosols at a Concentrated Dairy Operation. Aerobiologia, 26, 171-184. http://dx.doi.org/10.1007/s10453-010-9154-2

[5] Hinds, W.C. (1998) Aerosol Technology: Properties, Behavior, and Measurements of Airborne Particles. John Wiley \& Sons, INC., New York.

[6] Thorne, P.S., Ansley, A.C. and Perry, S.S. (2009) Concentrations of Bioaerosols, Odors, and Hydrogen Sulfide Inside and Downwind from Two Types of Swine Livestock Operations. Journal of Occupational and Environmental Hygiene, 6, 211-220. http://dx.doi.org/10.1080/15459620902729184

[7] Mohr, A.J. (1997) Fate and Transport of Microorganisms in Air. Environmental Microbiology, 641-650.

[8] Baron, P.A. and Willeke, K. (2001) Aerosol Measurement Principles, Techniques and Applications. 2nd Edition, John Wiley \& Sons, INC., New York.

[9] Cox, C.S. and Wathes, C.M. (1995) Bioaerosol Handbook. Lewis Publishers, New York.

[10] Tang, J.W. (2009) The Effect of Environmental Parameters on the Survival of Airborne Infectious Agents. Journal of the Royal Society Interface, 6, S737-S746. http://dx.doi.org/10.1098/rsif.2009.0227.focus

[11] Peccia, J., Werth, H.M., Miller, S. and Hernandez, M. (2001) Effects of Relative Humidity on the Ultraviolet Induced Inactivation of Airborne Bacteria. Aerosol Science and Technology, 35, 728-740. http://dx.doi.org/10.1080/02786820152546770

[12] Webb, S.J. (1959) Factors Affecting the Viability of Air-Borne Bacteria: I. Bacteria Aerosolized from Distilled Water. Canadian Journal of Microbiology, 5, 649-669. http://dx.doi.org/10.1139/m59-079

[13] Won, W.D. and Ross, H. (1966) Effect of Diluents and Relative Humidity on Apparent Viability of Airborne Pasteurella pestis. Applied Microbiology, 14, 742-745.

[14] Sabariego, S., de la Guardia, C.D. and Alba, F. (1999) The Effect of Meteorological Factors on the Daily Variation of Airborne Fungal Spores in Granada (Southern Spain). International Journal of Biometeorology, 44, 1-5. http://dx.doi.org/10.1007/s004840050131

[15] Ulevičius, V., Pečiulytė, D., Mordas, G. and Lugauskas, A. (2000) Field Study on Changes in Viability of Airborne Fungal Propagules Exposed to Solar Radiation. Journal of Aerosol Science, 31, 961-962. http://dx.doi.org/10.1016/S0021-8502(00)90971-6

[16] Predicala, B.Z., Urban, J.E., Maghirang, R.G., Jerez, S.B. and Goodband, R.D. (2002) Assessment of Bioaerosols in Swine Barns by Filtration and Impaction. Current Microbiology, 44, 136-140. http://dx.doi.org/10.1007/s00284-001-0064-y

[17] Jo, W.K. and Kang, J.H. (2005) Exposure Levels of Airborne Bacteria and Fungi in Korean Swine and Poultry Sheds. Archives of Environmental \& Occupational Health, 60, 140-146. http://dx.doi.org/10.3200/AEOH.60.3.140-146

[18] Lee, S.A., Adhikari, A., Grinshpun, S.A., McKay, R., Shukla, R. and Reponen, T. (2006) Personal Exposure to Airborne Dust and Microorganisms in Agricultural Environments. Journal of Occupational and Environmental Hygiene, 3, 118-130. http://dx.doi.org/10.1080/15459620500524607

[19] Clark, S., Rylander, R. and Larsson, L. (1983) Airborne Bacteria, Endotoxin and Fungi in Dust in Poultry and Swine Confinement Buildings. American Industrial Hygiene Association Journal, 44, 537-541. http://dx.doi.org/10.1080/15298668391405265

[20] Banhazi, T.M., Seedorf, J., Rutley, D.L. and Pitchford, W.S. (2005) Statistical Modeling of Airborne Bacteria and Endotoxins Concentrations in Australian Piggery Buildings. Livestock Environment VII: Proceedings of the 7th International Symposium, Beijing, 18-20 May 2005, 72-78.

[21] Crook, B., Robertson, J.F., Travers Glass, S.A., Botheroyd, E.M., Lacey, J. and Topping, M.D. (1991) Airborne Dust, Ammonia, Microorganisms, and Antigens in Pig Confinement Houses and the Respiratory Health of Exposed Farm Workers. American Industrial Hygiene Association Journal, 52, 271-279. http://dx.doi.org/10.1080/15298669191364721

[22] Predicala, B.Z., Urban, J.E., Maghirang, R.G., Jerez, S.B. and Goodband, R.D. (2001) Comparison of Bioaerosol Sampling Methods for Swine Barns. Swine Day, Manhattan, 15 November 2001, 127-130.

[23] Heederik, D., Brouwer, R., Biersteker, K. and Boleij, J.S.M. (1991) Relationship of Airborne Endotoxin and Bacteria Levels in Pig Farms with the Lung Function and Respiratory Symptoms of Farmers. International Archives of Occupational and Environmental Health, 62, 595-601. http://dx.doi.org/10.1007/BF00381114

[24] Wang-Li, L., Li, Q.F., Wang, K., Bogan, B.W., Ni, J.Q., Cortus, E.L. and Heber, A.J. (2013) The National Air Emissions Monitoring Study's Southeast Layer Site: Part I. Site Characteristics and Monitoring Methodology. Transaction of the ASABE, 56, 1157-1171. 
[25] Hu, D. (2012) Temporal and Spatial Variations of Bioaerosol Concentrations Emitted from an Egg Production Farm in Southeast US. Master's Thesis, North Carolina State University, Raleigh.

[26] Chang, C.W., Chung, H., Huang, C.F. and Su, H.J. (2001) Exposure of Workers to Airborne Microorganism Open-Air Swine Houses. Applied and Environmental Microbiology, 67, 155-161. http://dx.doi.org/10.1128/AEM.67.1.155-161.2001

[27] Hu, D., Wang-Li, L., Simmons, O.D., Classen, J.J., Osborne, J.A. and Byfield, G.E. (2014) Bioaerosol Concentrations and Emissions from Tunnel Ventilated High-Rise Layer Operation Houses in the United States. Transaction of ASABE, 57, 915-925. 